\title{
TECHNOLOGIE WYKONANIA PRZEPUSZCZALNYCH BARIER REAKTYWNYCH
}

\author{
Katarzyna Pawluk ${ }^{\bowtie}$, Marzena Lendo-Siwicka, Grzegorz Wrzesiński \\ Wydział Budownictwa i Inżynierii Środowiska, Szkoła Główna Gospodarstwa Wiejskiego w Warszawie, Warszawa
}

\begin{abstract}
STRESZCZENIE
Przepuszczalne bariery reaktywne (PBR) to jedna z innowacyjnych technologii zabezpieczania i oczyszczania środowiska gruntowo-wodnego i jednocześnie alternatywna w stosunku do energochłonnej metody „pompuj i oczyszczaj”. PBR to konstrukcja inżynierska w podłożu gruntowym wypełniona materiałem reaktywnym, w której podczas przepływu wód gruntowych dochodzi do przechwycenia zanieczyszczeń lub redukcji ich stężeń do wartości akceptowalnych. Od początku stosowania wykorzystano szereg technologii ich wykonania, obejmujących m.in. tradycyjne i alternatywne technologie wykopowe, iniekcję, mieszanie wgłębne oraz różne konstrukcje, w zależności od parametrów zanieczyszczeń i warunków terenowych. Pomimo szerokiego stosowania nadal istnieją nierozwiązane problemy dotyczące ich wykonania i długoterminowego działania. W artykule przedstawiono przegląd technologii PRB, który obejmuje stan techniki, zalety i ograniczenia oraz perspektywy zastosowania jej w Polsce.
\end{abstract}

Słowa kluczowe: przepuszczalne bariery reaktywne, technologie wykopowe, alternatywne metody budowy PBR, konstrukcja PBR

\section{WSTĘP}

Technologia przepuszczalnych barier reaktywnych (PBR) powstała na początku lat dziewięćdziesiątych ubiegłego wieku w Ameryce Północnej jako metoda innowacyjna i alternatywna w stosunku do energochłonnej metody „pompuj i oczyszczaj” (ang. pump and treat). Obecnie traktowana jest jako jedna z podstawowych metod zabezpieczania i oczyszczania środowiska gruntowo-wodnego. Na całym świecie zastosowano ponad tysiąc systemów PBR i w dalszym ciągu trwa intensywny rozwój tej technologii, polegający na wykorzystaniu nowych materiałów reaktywnych, innowacyjnych konstrukcji oraz technologii wykonania (Powell i in., 1998; Gavaskar, Gupta, Sass, Janosy i Hicks, 2000; Roehl, Huttenloch i Czurda, 2001; Naftz, Morrison, Fuller i Davis, 2002; ITRC, 2011; Obiri-Nyarko, Grajales-Mesa i Malina, 2014). Koncepcja technologii PBR opiera się na instalacji w gruncie prostopadle do kierunku przepływu wód gruntowych konstrukcji wypełnionej materiałem reaktywnym, w której podczas przepływu zanieczyszczeń dochodzi do ich immobilizacji lub oczyszczenia na drodze różnego rodzaju procesów fizycznych, chemicznych i biologicznych (Powell i in. 1998). Działanie PBR z niewielką potrzebą lub bez potrzeby dodatkowej obsługi i konserwacji, w zależności od projektu i rodzaju konstrukcji, jest liczone w latach lub dekadach, ponieważ są one zaprojektowane jako systemy pasywne.

$\mathrm{W}$ artykule przedstawiono przegląd technologii PRB oraz perspektywy zastosowania jej w Polsce. Ponadto na podstawie dotychczasowych doświadczeń ukazano problemy dotyczące ich wykonania, długoterminowego działania oraz kosztów.

$\unrhd_{\text {katarzyna_pawluk@sggw.pl }}$ 


\section{ZASADY PROJETOWANIA I KONSTRUKCJA PRZEPUSZCZALNYCH BARIER REAKTYWNYCH}

Konstrukcja PBR zależy od właściwości i lokalizacji plamy zanieczyszczeń w podłożu gruntowo-wodnym. PBR może być zlokalizowana tuż przy źródle, aby umożliwiać natychmiastowe przechwytywanie zanieczyszczeń, lub w znacznej odległości, wspomagając zjawisko samooczyszczania się środowiska gruntowo-wodnego. PBR powinna spełniać dwie podstawowe funkcje (USEPA, 1997, 1999; ITRC, 2011). Pierwszą z nich jest przechwytywanie i immobilizacja przemieszczających się wraz z wodami gruntowymi zanieczyszczeń do poziomu akceptowalnego. Drugą funkcją jest zapewnienie optymalnych warunków przepływu zanieczyszczeń przez strefę oczyszczania, nie dopuszczając do ich „opływania” (poniżej lub powyżej strefy). Analiza wyników szczegółowych badań terenowych, laboratoryjnych i numerycznych umożliwia instalację PBR w zanieczyszczonym podłożu tak, aby zapewnić właściwe oczyszczenie środowiska gruntowo-wodnego (Gavaskar i in., 2000; Malina, 2007; Fronczyk, 2008).

W literaturze przedstawiono różne stosowane w praktyce rozwiązania konstrukcyjne PBR, w tym ciagłe, kombinowane otwarte (system „lejkowy”) i zamknięte oraz wielowarstwowe bariery reaktywne (multibariery, bariery sekwencyjne). W praktyce najczęściej stosowane są pierwsze dwie, to znaczy PBR ciagła i PBR kombinowana otwarta (Carey, Fretwell, Mosley i Smith, 2002). Najprostszym systemem jest ciagła bariera reaktywna, w całości wypełniona materiałem reaktywnym, która jest stosowana na terenach o homogenicznym i dobrze przepuszczalnym podłożu. System kombinowany zalecany jest w przypadku warunków heterogenicznych, gdzie może być efektywnym i skutecznym sposobem oczyszczania wód podziemnych. Bariera kombinowana otwarta składa się z nieprzepuszczalnych ścianek szczelnych (stalowych lub prefabrykowanych) bądź też ścian szczelinowych z zawiesiną samotwardniejąca, stanowiących strefę kierunkową, której zadaniem jest skierowanie strumienia zanieczyszczeń do jednej lub wielu stref oczyszczania wypełnionych materiałem reaktywnym. Ponadto bariery kombinowane mogą być zamknięte, kiedy występują w postaci barier nieprzepuszczalnych otaczających źródło zanieczyszczenia. Zastosowanie systemów kombinowanych obniża koszt wykonania PBR, ponieważ konstrukcje te w stosunku do innych wymagają mniejszej ilości materiałów wypełniających barierę oraz umożliwiają prowadzenie dokładniejszego monitoringu procesów oczyszczania (USEPA, 1999; Gavaskar i in., 2000; Fronczyk, 2008; Suponik, 2010; Pawluk, 2011).

Zarówno w przypadku systemu ciągłego, jak i kombinowanego wymiary bariery zależą przede wszystkim od stężenia zanieczyszczeń oraz od wymaganych standardów jakości wód wypływających ze strefy reaktywnej. W praktyce najczęściej przyjmuje się, że długość bariery powinna być większa niż szerokość plamy zanieczyszczeń, podczas gdy szerokość (miąższość) zależy od wymaganego czasu przebywania zanieczyszczeń w strefie oczyszczania oraz prędkości przepływu wody gruntowej (Malina, 2007; Fronczyk, 2008; ITRC, 2011; Pawluk, 2011).

\section{TECHNOLOGIE WYKONANIA PBR}

W praktyce wykorzystywanych jest wiele metod instalacji przepuszczalnych barier reaktywnych. Wybór technologii zależy od kilku czynników, m.in. od wymiarów PBR, materiału reaktywnego, rodzaju systemu (ciagły, kombinowany), geologii i użytkowania terenu (np. budynki, instalacje techniczne). Duże znaczenie ma również ilość materiału reaktywnego i szerokość strefy oczyszczania, które w znacznym stopniu mogą ograniczać wybór tradycyjnych metod.

Technologie wykopowe należą do najprostszych i najtańszych metod wykonania PBR przy użyciu tradycyjnego sprzętu. Wykop wykonany za pomocą koparek jednonaczyniowych bez zabezpieczenia (rys. 1a) może być wykonany do głębokości $10 \mathrm{~m}$, natomiast z zabezpieczeniem - do głębokości $60 \mathrm{~m}$. Do zabezpieczenia wykopu stosuje się ścianki szczelne (rys. 1b), które mogą również służyć do oddzielenia poszczególnych warstw w multibarierach podczas zasypywania wykopu materiałem/ami, lub systemy typu box (rys. 1c). 
a

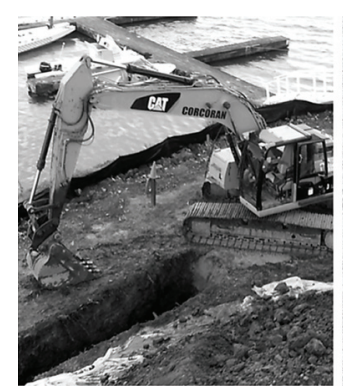

b

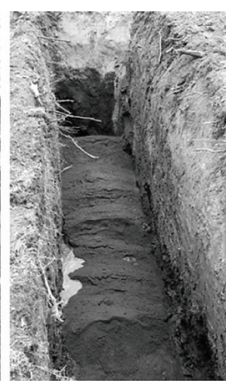

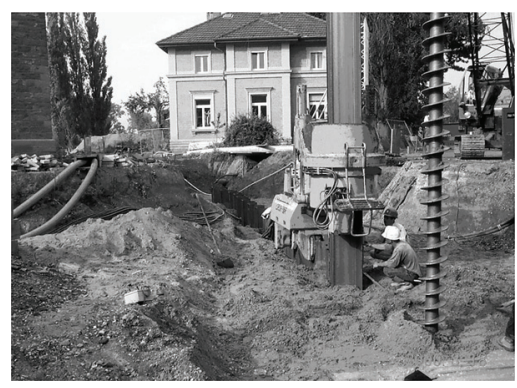

$\mathrm{c}$

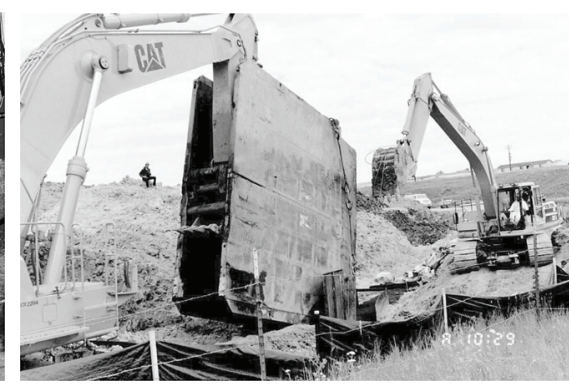

Rys. 1. Wykop bez zabezpieczeń, wykonanie bariery ciągłej z żelaza zero-wartościowego ZVI (Vertex Environmental, 2015) - a; wykop zabezpieczony ściankami szczelnymi przed wypełnieniem ZVI, Karlsruhe, Niemcy (RUBIN, 2006) - b; wykop zabezpieczony za pomocą systemu typu box - instalacja kombinowanej PBR z ZVI w Cheyenne, WY, USA (RTDF, 2001) - c

Fig. 1. Unsupported excavation, installation of continuous, zero-valent iron ZVI barrier (Vertex Environmental, 2015) - a; sheet piling before ZVI filling, Karlsruhe, Germany (RUBIN, 2006) - b; temporary trench box - PRB gate system ZVI, Cheyenne, WY, USA (RTDF, 2001) - c

Wykorzystując do budowy wykopu koparki wielonaczyniowe, np. łańcuchowe, możliwe jest wykonanie wykopu ciagłego. Zastosowanie tego rodzaju maszyn umożliwia jednoczesne wykonywanie wykopu i wypełnianie go materiałem reaktywnym. Wykop może być wykonywany bez wcześniejszego odwodnienia i zabezpieczenia. Wykonanie robót tym sposobem umożliwia zainstalowanie bariery o szerokości w zakresie 0,3-0,9 m oraz głębokości do 10-12 m. Wykop ciągły należy do metod mało czasochłonnych, lecz wymagających dużych nakładów finansowych (Roehl Czurda, Meggyes, Simon i Stewart, 2005; Simon i Biermann, 2007; ITRC, 2011). W 1999 roku technologia ta została z powodzeniem wykorzystana do budowy wielu PBR na terenie Stanów Zjednoczonych, m.in. w 1999 roku do instalacji bariery zeolitowej w West Valley, New York oraz w 2005 roku do instalacji biobariery Ellsworth AFB, South Dakota (Sivavec, Krug, Berry-Spark i Focht, 2002; ITRC, 2011).

W większości przypadków zalecane jest wykonanie pełnej PBR osiagającej warstwę utworów słabo przepuszczalnych, w związku z tym konieczna jest budowa wykopu z zabezpieczeniami. Przykładem technologii wykopowej umożliwiającej zabezpieczenie ścian wykopu jest tak zwany wykop biopolimerowy (rys. 2a). Technologia ta polega na wypełnieniu wykopu zawiesiną biodegradowalną (biopolimer na bazie gumy guar) w celu stabilizacji, analogicznie jak w przypadku technologii ściany szczelinowej. Następnie materiał reaktywny jest wprowadzany do wykopu iniekcyjnie (z dołu do góry) za pośrednictwem rury kontraktorowej. Biopolimer usuwany jest $\mathrm{z}$ wykopu za pomocą studni recylkulacyjnych instalowanych wzdłuż wykopu oraz w procesie naturalnej biodegradacji. Technologia ta nie wymaga wcześniejszego odwodnienia i umożliwia wykonanie PBR do głębokości 10-60 m. Zaletą tej metody są niskie koszty, natomiast wadą - konieczność pozyskania dużej powierzchni roboczej. Przykładami zastosowania tej technologii są bariery z żelaza zero-wartościowego zainstalowane w 2000 roku na terenie składowiska Somersworth w New Hampshire (USA) oraz w 2010 roku na terenie składowiska w Bellevue w Australii (Day, O’Hannesin i Marsden, 1999; Gavaskar i in., 2000; ITRC, 2005, 2011; Roehl i in., 2005).

Kolejnym przykładem wykopu z zabezpieczeniami jest technologia ścianek szczelnych. Instalacja ścianek stalowych (rys. 2b) lub z tworzywa sztucznego, stanowiących szkielet przyszłej PBR, może być przeprowadzona za pomocą następujących metod: wibracyjnej, pneumatycznej i wciskania. Z podłoża ograniczonego ściankami wydobywa się grunt i wypełnia przestrzeń materiałem reaktywnym, po czym usuwa się szkielet ze ścianek 

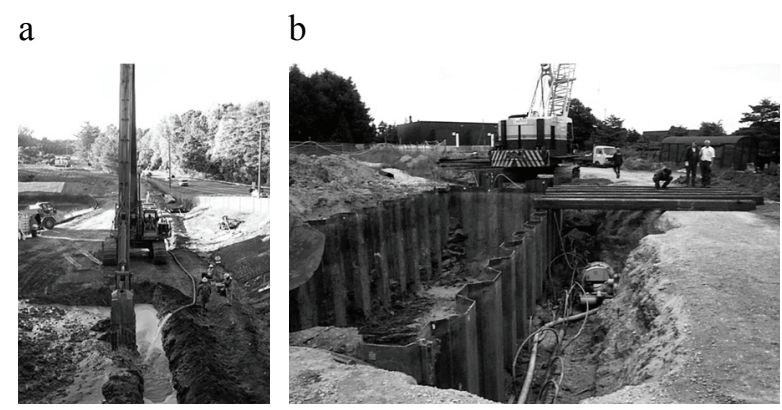

Rys. 2. Wykop zabezpieczony biopolimerem - instalacja bariery z żelaza zero-wartościowego w Marietta, GA, USA (Geo-Solutions, 2017) - a; ścianki szczelne wykorzystane podczas instalacji PBR w Søndersø, Dania (RTDF, 2001) - b

Fig. 2. Biopolymer trench construction - installation of a zero valent iron barrier in Marietta, GA, USA (Geo-Solutions, 2017) - a; sheet piling using during installation of PRB in Søndersø, Denmark (RTDF, 2001) - b

w celu umożliwienia swobodnego przepływu wód gruntowych przez PBR. Ścianki szczelne można również stosować do budowy barier nieprzepuszczalnych (kierunkujących przepływ zanieczyszczeń w strefę tzw. bramki) w konstrukcji kombinowanej lub jako separator poszczególnych warstw materiałów podczas budowy multibariery. Niewątpliwą zaletą tej metody są niskie koszty, krótki czas trwania robót oraz możliwość wykonania bariery do głębokości $10 \mathrm{~m}$. Technologia została wykorzystana zarówno do budowy jednych z pierwszych PBR z żelaza zero-wartościowego w 1991 roku w Borden, Kanada, w 1996 roku w Lakewood, Colorado USA oraz w Søndersø w Dani (rys. 2b), jak i do budowy ostatnich inwestycji, np. w 2007 roku PBR z żelaza zero-wartościowego i EHC w Sunyvale, USA (Smith, Cherry i Jowett, 1995; Gavaskar i in., 2000; Fiorenza, Oubre i Ward, 2000; Roehl i in., 2005; ITRC, 2011)

Budowa PBR może być również realizowana za pomocą technologii iniekcyjnych, spośród których należy wymienić metodę bezpośrednią, szczelinowanie hydrauliczne i wysokociśnieniowej iniekcji. Pierwsza metoda polega na wprowadzaniu materiału reaktywnego w postaci emulsji (np. ZVI, EHC w mieszaninie z woda) pod ciśnieniem przez odwierty (rys. 3a). Ponadto przy zastosowaniu specjalistycznego sprzętu wyposażonego w głowicę iniekcyjną (Ferox ${ }^{\mathrm{SM}}$ ), wykorzystując technikę bezpośredniej iniekcji, możliwe jest obniżenie kosztów instalacji i wykonywanie jednoczesnej iniekcji w kilku punktach. Maksymalna głębokość bariery może

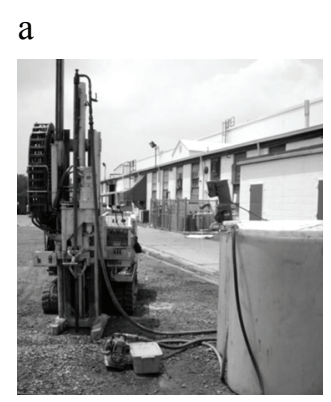

b

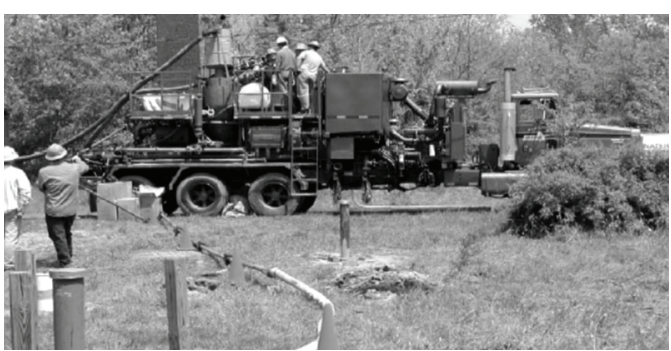

Rys. 3. Budowa PBR metodą bezpośredniej iniekcji w Trenton Facility, NJ, USA (NanoRem, 2017) - a; sprzęt do instalacji PBR z nZVI metodą szczelinowania hydraulicznego (Clean-up Information, 2017) - b

Fig. 3. Direct Injection of PRB installation in Trenton Facility, NJ,USA (NanoRem, 2017) - a; hydraulic fracturing equipment of zero valent iron PRB (Clean-up Information, 2017) - b 
wynieść w tym przypadku $10 \mathrm{~m}$. Technologia została wykorzystana z powodzeniem w 2001 i 2002 roku do budowy barier z ZVI na terenie bazy lotów kosmicznych Marshall Space Flight Center, Huntsville, Alabama oraz na terenie bazy marynarki wojennej w Hunters Point Shipyard, San Francisco, USA (Clean-up Information, 2017).

Druga metoda polega na wykonaniu odwiertu i wprowadzeniu do niego rur okładzinowych, które następnie zostają zacementowane. W wybranych miejscach sekcje rur są perforowane, aby umożliwić wysokociśnieniową iniekcję wody z dodatkami chemicznymi, która powoduje tworzenie się w podłożu gruntowym spękań lub szczelin. Do odwiertu, a następnie do szczelin w podłożu wprowadzana jest iniekcyjnie mieszanina wody lub biopolimeru z materiałem reaktywnym. Technologia ta umożliwia wykonanie zarówno barier poziomych, jak i pionowych. Głębokość bariery wykonanej tą technologią może wynosić maksymalnie $60 \mathrm{~m}$. W 2002, 2007 i 2009 roku technologię tę wykorzystano do budowy PBR z żelaza zero-wartościowego na terenach poprzemysłowym Arrowhead Plating, w Montross, Virginia (USA) i Medford, New Jersey, USA (rys. 3b), Hookston Station w Pleasant Hill, California, USA (Gavaskar i in., 2000; ITRC, 2005, Roehl i in, 2005; GSEI, 2017).

Natomiast technologia wysokociśnieniowego wtryskiwania polega na niszczeniu naturalnej struktury gruntu strumieniem iniektu pod wysokim ciśnieniem za pomocą potrójnej dyszy świdra/głowicy wiertnicy. Budowa bariery może odbywać się jednoetapowo. Wówczas iniekt wprowadzany jest w postaci mieszaniny materiału reaktywnego w zawiesinie biodegradowalnej, powietrza i/lub wody lub dwuetapowo przy zastosowaniu zawiesiny wody z dodatkami chemicznym. W efekcie cząstki gruntu ulegają odspajaniu i wypłukiwaniu po żerdzi na powierzchnię terenu. W metodzie dwuetapowej następuje wypompowywanie zawiesiny z jednoczesną iniekcją materiału reaktywnego. W obu metodach podczas iniekcji następuje jednoczesne unoszenie się i obracanie żerdzi, które powoduje formowanie w gruncie tzw. pali iniekcyjnych. Technologia wysokociśnieniowego wtryskiwania pozwala na formowanie barier ciagłych i kombinowanych lub kolumn o średnicy 2 m do głębokości 100 m (Gavaskar i in., 2000; Puls, 2006; ITRC, 2011). Za pomocą tej technologii wykonano PBR z żelaza zero-wartościowego w 1999 oraz 2004 roku na terenie poprzemysłowym w Monticello, Utah, USA.

Przykładem technologii wierceń jest mieszanie wgłębne (rys. 4), które polega na jednoczesnym wprowadzaniu materiału reaktywnego i mieszaniu go z zanieczyszczonym gruntem za pomocą świdrów ciagłych, mieszających (wyposażonych w dysze), umieszczonych na wiertnicy (wieżowej lub samojezdnej). Technologia umożliwia wykonanie barier w postaci kolumn, barier ciągłych i kombinowanych do głębokości $15 \mathrm{~m}$. Ze względu na wysokie koszty nie jest opłacalna na małych obiektach budowlanych. W 2009 roku na terenie baz sił lotniczych w Vandenberg, California, USA za pomocą tej technologii wykonano barierę z mieszanki węgla aktywnego z żelazem zero-wartościowym (Gavaskar i in., 2000; Roehl i in., 2005; ITRC, 2011).

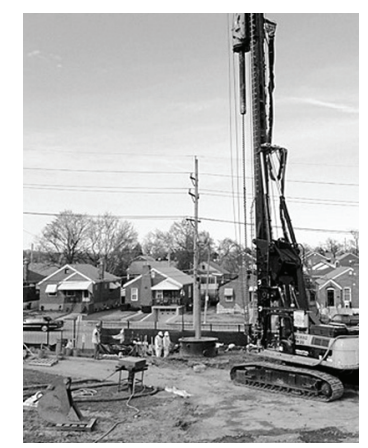

Rys. 4. Instalacja PBR za pomocą mieszania wgłębnego w St. Louis, MO, USA (Geo-Solutions, 2017)

Fig. 4. PRB application using soil mixing in St. Louis, MO, USA (Geo-Solutions, 2017) 
Drugim przykładem z tej grupy technologii jest odwiert wykonywany w stalowej osłonie o maksymalnej średnicy 2,5 m. Usunięcie osłony poprzedzone jest wypełnieniem pustej przestrzeni materiałem reaktywnym. W celu otrzymania bariery ciągłej wykonuje się kilka odwiertów w jednej linii. Metoda nie wymaga odwodnienia i umożliwia wykonanie PBR do głębokości $20 \mathrm{~m}$. Za pomocą tej technologii w 1999 roku w Cape Canaveral, USA wykonano strefę oczyszczania z żelaza zero-wartościowego bariery kombinowanej (Carey i in., 2002; Roehl i in., 2005; Simon i Biermann, 2007; ITRC, 2011).

W tabeli 1 przedstawiono zestawienie całkowitych kosztów wykonania i materiałów reaktywnych dla wybranych instalacji PBR (RTDF, 2001; ITRC, 2011). Inwestycje różniły się skalą, technologią wykonania, warunkami środowiskowymi oraz wykorzystanymi materiałami. Porównując koszt wykonania $1 \mathrm{~m}^{3}$ bariery z ZVI, to dla technologii wykopowej bez zabezpieczenia wynosił on 1000 USD, dla wykopu ciagłego - 905,80 1666,67 USD, dla wykopu zabezpieczonego biopolimerem - 2053,33 USD, dla technologii ścianek szczel-

Tabela 1. Zestawienie technologii i kosztów wykonania PBR

Table 1. Summary of technology and costs of PBR installation

\begin{tabular}{|c|c|c|c|c|c|c|}
\hline $\begin{array}{l}\text { Miejsce } \\
\text { Location }\end{array}$ & $\begin{array}{l}\text { Technologia } \\
\text { wykonania } \\
\text { Technology of } \\
\text { installation }\end{array}$ & $\begin{array}{c}\text { Rok instalacji } \\
\text { Year } \\
\text { installed }\end{array}$ & $\begin{array}{l}\text { Materiał } \\
\text { reaktywny } \\
\text { Reactive } \\
\text { material }\end{array}$ & $\begin{array}{c}\text { Objętość PBR } \\
{\left[\mathrm{m}^{3}\right]} \\
\text { Volume of PRB } \\
{\left[\mathrm{m}^{3}\right]}\end{array}$ & $\begin{array}{c}\text { Koszt } \\
\text { wykonania } \\
{[\text { USD] }} \\
\text { Installation cost } \\
\text { [USD] }\end{array}$ & $\begin{array}{c}\text { Koszt } \\
\text { wykonania } 1 \mathrm{~m}^{3} \\
\text { [USD] } \\
\text { Installation cost } \\
\text { of } 1 \mathrm{~m}^{3} \text { [USD] }\end{array}$ \\
\hline $\begin{array}{l}\text { Nickel Rim } \\
\text { Mine Site, USA }\end{array}$ & $\begin{array}{l}\text { wykop bez } \\
\text { zabezpieczeń } \\
\text { unsupported } \\
\text { excavation }\end{array}$ & 1995 & $\begin{array}{c}\text { węgiel } \\
\text { organiczny }\end{array}$ & 62 & 30000 & 483,87 \\
\hline $\begin{array}{l}\text { Sunnyvale, CA, } \\
\text { USA }\end{array}$ & $\begin{array}{c}\text { wykop bez } \\
\text { zabezpieczeń } \\
\text { unsupported } \\
\text { excavation }\end{array}$ & 2007 & ZVI, EHC & 2100 & 2100000 & 1000,00 \\
\hline $\begin{array}{l}\text { Elizabeth City, } \\
\text { NC, USA }\end{array}$ & $\begin{array}{l}\text { wykop ciagły } \\
\text { continuous } \\
\text { trench }\end{array}$ & 1996 & ZVI & 193 & 175000 & 905,80 \\
\hline $\begin{array}{l}\text { Altus AFB, OK, } \\
\text { USA }\end{array}$ & $\begin{array}{l}\text { wykop ciagły } \\
\text { continuous } \\
\text { trench }\end{array}$ & 2002 & kompost & 486 & 325800 & 669,68 \\
\hline $\begin{array}{l}\text { Haardrom } \\
\text { Site, Kolding, } \\
\text { Holandia }\end{array}$ & $\begin{array}{l}\text { wykop ciagły } \\
\text { continuous } \\
\text { trench }\end{array}$ & 2005 & ZVI & 150 & 250000 & 1666,67 \\
\hline $\begin{array}{l}\text { Grand Island, } \\
\text { NB }\end{array}$ & $\begin{array}{c}\text { wykop } \\
\text { zabezpieczony } \\
\text { biopolimerem } \\
\text { biopolymer } \\
\text { trench } \\
\text { construction }\end{array}$ & 2003 & ZVI & 66 & 138600 & 2053,33 \\
\hline $\begin{array}{l}\text { Chalk River, } \\
\text { OK, USA }\end{array}$ & $\begin{array}{l}\text { ścianki szczelne } \\
\text { sheet piling }\end{array}$ & 1998 & zeolit & 132 & 360000 & 2727,27 \\
\hline Søndersø, Dania & $\begin{array}{l}\text { ścianki szczelne } \\
\text { sheet piling }\end{array}$ & 1999 & ZVI & 81 & 700000 & 8641,98 \\
\hline
\end{tabular}




\begin{tabular}{|c|c|c|c|c|c|c|}
\hline \multirow{2}{*}{$\begin{array}{l}\text { Port Huenem, } \\
\text { CA, USA }\end{array}$} & $\begin{array}{c}\text { bezpośrednia } \\
\text { iniekcia }\end{array}$ & 2003 & ZVI & 9000 & 808000 & 89,78 \\
\hline & direct injection & & & 7200 & 500000 & 69,44 \\
\hline Midwest, USA & $\begin{array}{l}\text { iniekcja } \\
\text { injection }\end{array}$ & 2005 & ZVI, EHC & 820 & 299700 & 365,49 \\
\hline $\begin{array}{l}\text { Jacksonville, } \\
\text { North Carolina }\end{array}$ & $\begin{array}{l}\text { mieszanie } \\
\text { wgłębne } \\
\text { soil mixing }\end{array}$ & 2005 & ZVI & 24756 & 500000 & 20,20 \\
\hline
\end{tabular}

nych - 8641,98 USD, dla technologii iniekcyjnej - 69,44-365,49 USD, a dla zastosowania mieszania wgłębnego - 20,20 USD. Najtańszym wariantem wykonania było mieszanie wgłębne, a najdroższym technologia ścianek szczelnych. W przypadku mieszania wgłębnego koszty były zaniżone ze względu na wykorzystanie mniejszej objętości materiału reaktywnego (w stosunku do objętości PBR), który był mieszany z gruntem. Biorąc pod uwagę rzeczywistą ilość materiałów reaktywnych i ich koszty zakupu, to technologia wykopowa bez zabezpieczenia oraz iniekcja charakteryzowały się najniższymi kosztami wykonania.

\section{PODSUMOWANIE}

Technologia PBR jest powszechnie wykorzystywana w USA, Kanadzie, jak również coraz częściej w krajach UE (Austria, Belgia, Wielka Brytania, Niemcy, Włochy) oraz w Japonii, Australii i Nowej Zelandii. W Polsce dotychczas nie wykorzystywano tej technologii, natomiast prowadzone są liczne prace badawcze nad możliwością jej zastosowania (Suponik i Lutyński, 2009; Suponik, 2010, 2011; Bednarek, Stolarska, Ubraniak i Zalewski, 2010; Zawierucha i Malina, 2014; Pawluk i Fronczyk, 2015; Pawluk, Fronczyk i Garbulewski, 2015; Pawluk, 2016). W Katedrze Geoinżynierii SGGW od 2003 roku opracowywane są wytyczne do projektowania PBR w rejonach oddziaływania składowisk odpadów oraz infrastruktury drogowej. W Jaworznie w ramach projektu FOKS w zakresie działań zmierzających do rozwiązania problemu odpadów niebezpiecznych zgromadzonych w dolinie potoku Wąwolnica planowane jest wykonanie trzech systemów kombinowanych PBR w technologii ścianek szczelnych typu Larsena oraz technologii bezpośredniej iniekcji nano-węgla (Wytyczne do projektu..., 2016).

Technologia PBR posiada szereg zalet, spośród których należy wymienić: brak konieczności dostarczania energii (system pasywny), długi czas pracy (nawet 20-30 lat), możliwość zastosowania technologii na terenach zurbanizowanych i korzystania z terenu podczas procesu remediacji, możliwość wykorzystania tradycyjnych metod i sprzętu do jej budowy oraz minimalnego wpływu na środowisko naturalne.

Przeszkodą w stosowaniu technologii PBR są wysokie koszty instalacji, dlatego bardzo ważne jest właściwe rozpoznanie terenu, skali i charakterystyki zanieczyszczeń oraz dobór właściwej technologii wykonania. Technologia PBR wskazana jest na obszarach o szerokim zasięgu skażenia, gdzie może być zastosowana samodzielnie lub jako metoda wspomagająca. Koszty mogą zostać ograniczone poprzez zastosowanie metod wykopowych przy użyciu tradycyjnego sprzętu, konstrukcji kombinowanej otwartej i/lub zastosowanie lokalnych, tańszych materiałów reaktywnych. W przypadku planowania i organizacji robót dotyczących wykonania PBR w terenie niezbędne jest wykorzystanie narzędzi optymalizacyjnych w celu zminimalizowania kosztów oraz wydłużenia efektywnej pracy bariery, które to będą przedmiotem przyszłych prac Katedry Geoinżynierii SGGW. 
Pawluk, K., Lendo-Siwicka, M. i Wrzesiński, G. (2017). Technologie wykonania przepuszczalnych barier reaktywnych. Acta Sci. Pol. Architectura, 16 (2), 91-99. doi: 10.22630/ASPA.2017.16.2.12.

\section{PIŚMIENNICTWO}

Bednarek, A., Stolarska, M., Ubraniak, M. i Zalewski, M. (2010). Application of permeable reactive barrier for reduction of nitrogen load in the agricultural areas - preliminary results. Ecohydrology \& Hydrobiology, 10(2-4), 355-361. doi: 10.2478/v10104-011-0007-6

Carey, M. A., Fretwell, B.A., Mosley, N. G. i Smith, J. W. N. (2002). Guidance on the use of permeable reactive barriers for remediating contaminated groundwater. National Groundwater \& Contaminated Land Centre report NC/01/51. Bristol: UK Environment Agency.

Clean-up Information (2017). Permeable reactive barriers, permeable treatment zones, and application of zero-valent iron. Pobrano z lokalizacji: http://www.clu-in.org/.

Day, S. R., O’Hannesin, S. F. i Marsden, L. (1999). Geotechnical techniques for the construction of reactive barriers. Journal of Hazardous Materials, 67(3), 285-297. doi: 10.1016/S0304-3894(99)00044-8.

Fiorenza, S., Oubre, C. i Ward, C. (2000). Sequenced reactive barriers for groundwater remediation. Boca Raton, Florida: Lewis Publishers.

Fronczyk, J. (2008): Wykorzystanie mieszanek zeolitowo-piaskowych $w$ przepuszczalnych barierach reaktywnych $w$ rejonie składowisk odpadów. Rozprawa doktorska. Warszawa: SGGW.

Gavaskar, A., Gupta, N., Sass, B., Janosy, R. i Hicks, J. (2000). Design guidance for application of permeable reactive barriers for groundwater remediation. Columbus, $\mathrm{OH}$ : Battelle.

[GS] - Geo-Solutions (2017). Marietta, GA: Bio-Polymer Slurry Trench, Permeable Reactive Barrier Installation at Air Force Plant 6. Pobrano z lokalizacji: http://www.geo-solutions.com/.

[GSEI] - GeoSierra Environmental Inc. (2017). Projects. Pobrano z lokalizacji: http://www.geosierraenv.com/projects. html.

[ITRC] - Interstate Technology \& Regulatory Council (2005). Permeable Reactive Barriers: Lessons Learned/New Directions. PRB-4. Washington, D.C.: Interstate Technology \& Regulatory Council, Permeable Reactive Barriers Team. Pobrano z lokalizacji: http://www.itrcweb.org.

[ITRC] - Interstate Technology \& Regulatory Council (2011). Permeable Reactive Barrier: Technology Update. PRB-5. Washington, D.C.: Interstate Technology \& Regulatory Council, PRB: Technology Update Team. Pobrano z lokalizacji: http://www.itrcweb.org.

Malina, G. (2007). Likwidacja zagrożenia środowiska gruntowo-wodnego na terenach zanieczyszczonych. Częstochowa: Wydawnictwo Politechniki Częstochowskiej.

Naftz, D. L., Morrison, S. J., Fuller, C. C. i Davis, J. A. (2002). Handbook of Groundwater Remediation Using Permeable Reactive Barriers: Applications to Radionuclides, Trace Metals, and Nutrients. Amsterdam: Elsevier.

NanoRem (2017). Application of nZVI in Remediation. Pobrano z lokalizacji: http://www.nanorem.eu/.

Obiri-Nyarko, F., Grajales-Mesa, J. i Malina, G. (2014). An overview of permeable reactive barriers for in situ sustainable groundwater remediation. Chemosphere, 111, 243-259. doi: 10.1016/j.chemosphere.2014.03.112.

Pawluk, K. (2011). Konstrukcje inżynierskie wspomagające procesy oczyszczania środowiska gruntowo-wodnego. Przeglad Naukowy Inżynieria i Kształtowanie Środowiska, 53 (3), 258-271.

Pawluk, K. (2015). Charakterystyka właściwości mechanicznych wybranych materiałów reaktywnych. Acta Scientiarum Polonorum Architectura, 14(3), 57-66.

Pawluk, K. i Fronczyk, J. (2015). Evaluation of single and multilayered reactive zones for heavy metals removal from stormwater. Environmental Technology, 36(12), 1576-1583. doi: 10.1080/09593330.2014.997299.

Pawluk, K., Fronczyk J. i Garbulewski, K. (2015). Reactivity of nano zero-valent iron in permeable reactive barriers. Polish Journal of Chemical Technology, 17(1), 7-10. doi: 10.1515/pjct-2015-0002.

Powell, R. M., Blowes, D., Gillham, R. W., Schultz, D., Sivavec, T., Puls, R. W., ... i Landis, R. (1998). Permeable reactive barrier technologies for contaminant remediation, EPA/600/R-98/125. Washington DC: EPA.

Puls, R. (2006). Long-term performance of permeable reactive barriers: Lessons learned on design, contaminant treatment, longevity, performance monitoring and cost - an overview. W I. Twardowska i in. (red.), Soil and water pollution monitoring. Protection and Remediation. (strony 221-229). Dordrecht: Springer.

[RTDF] - Remediation Technology Development Forum (2001). Permeable reactive barriers installation profiles. Pobrano z lokalizacji: https://rtdf.clu-in.org/. 
[RUBIN] - Reinigungswände und -barrieren im Netzwerkverbund (2006). RUBIN project. Pobrano z lokalizacji: http:// www.rubin-online.de/.

Roehl, K. E., Huttenloch, P. i Czurda, K. (2001). Permeable sorption barriers for in-situ remediation of polluted groundwater - reactive materials and reaction mechanisms. W Green 3, The Exploitation of Natural Resources and the Consequences. (strony 466-473). London: Thomas Telford Publishing.

Roehl, K. E., Czurda, K., Meggyes, T., Simon, F. i Stewart, D.I. (2005). Long-term performance of permeable reactive barriers. Amsterdam: Elsevier.

Simon, F. G. i Biermann, V. (2007). Groundwater remediation using permeable reactive barriers. Land Contamination and Reclamation, 15, 31-39.

Sivavec, T., Krug, T., Berry-Spark, K. i Focht, R. (2002). Performance monitoring of permeable reactive barrier at Somersworth, NH Landfill Superfund Site. W F.G. Simon, T. Meggyes. i C. McDonald (red.), Advanced Groundwater Remediation - Active and Passive Technologies. (strony 87-100). London: Thomas Telford.

Smith, D., Cherry, J. i Jowett, R. (1995). Sealable Joint Steel Sheet Piling for Groundwater Pollution Control. W Proceedings of ER '95: Committed to Results. U.S. Department of Energy. Denver, CO.

Suponik, T. (2010). Adsorption and Biodegradation in PRB Technology. Environment Protection Engineering, 36(3), 43-57.

Suponik, T. (2011). Optimization of the PRB (Permeable Reactive Barriers) parameters for selected area of dumping site. Gliwice: The Publishing House of the Silesian University of Technology.

Suponik, T. i Lutyński, M. (2009). Possibility of Using Permeable Reactive Barrier in Two Selected Dumping Sites. Archives of Environmental Protection, 35(3), 109-122.

[USEPA] - United States Environmental Protection Agency (1997). Permeable reactive subsurface barriers for the interception and remediation of chlorinated hydrocarbon and chromium (VI) plumes in ground water EPA/600/f-97/008. Washington: USEPA.

[USEPA] - United States Environmental Protection Agency (1999). Batch - Type Adsorption Procedures for Estimating Soil Attenuation of Chemicals EPA 530/SW-87-006. Washington: USEPA.

Vertex Environmental (2015). PRB Design and Insallation. Pobrano z lokalizacji: http://vertexenvironmental.ca/2015/10prbdesign-and-installation/.

Wytyczne do projektu technicznego remediacji/rekultywacji terenów zanieczyszczonych $w$ dolinie potoku Wawolnica $w$ Jaworznie (2016). Urząd Miejski w Jaworznie. Pobrano z lokalizacji: http://bip.jaworzno.pl/.

Zawierucha, I. i Malina, G. (2014). Zastosowanie zeolitu do usuwania jonów metali śladowych z wody w technologii przepuszczalnych barier aktywnych. Ochrona Środowiska, 36(1), 39-44.

\section{TECHNOLOGIES FOR THE CONSTRUCTION OF PERMEABLE REACTIVE BARRIERS}

\section{SUMMARY}

Permeable reactive barriers (PRB) is one of the innovative technologies of ground-water remediation and alternative to energy-intensive method "pump and treat". The PBR is the engineering construction in the ground, filled with reactive material, where the contaminants from groundwater flow are immobilized or reduce to acceptable values. Since the invention of PRBs, a several installation methods were used to construct including conventional and alternative trenching techniques, injection, deep soil mixing and various type of construction depending on the parameters of contaminants and field conditions. Despite a wide ranging, there are still unresolved issues about installation methods and long term-performance. This article presents an overview of the PRB technology, which includes state of the art, advantages and limitations, and prospects for the use in Poland.

Key words: permeable reactive barriers, excavation technology, alternative installation method of PRB, construction of PRB 